\title{
Substitution and Haplotype Diversity Analysis on the Partial Sequence of the Mitochondrial DNA Cyt b of Indonesian Swamp Buffalo (Bubalus bubalis)
}

\author{
Akhmad Sukri ${ }^{1 *}$, Mohamad Amin ${ }^{2}$, Aris Winaya ${ }^{3}$ and Abdul Gofur ${ }^{2}$ \\ ${ }^{1}$ Department of Biology, IKIP Mataram, Jl. Pemuda No. 59A Mataram, Nusa Tenggara Barat, Indonesia \\ ${ }^{2}$ State University of Malang, Jalan Semarang 5 Malang 65145, East Java, Indonesia \\ ${ }^{3}$ University of Muhammadiyah Malang, Jl. Bandung 1 Malang, East Java, Indonesia \\ Author correspondency*: \\ sukri_bio04@yahoo.co.id
}

\begin{abstract}
This research aims to investigate the substitution pattern of nucleotide base and haplotype diversity of Indonesian swamp buffalo (Bubalus bubalis) based on the mitochondrial DNA cyt b partial gene sequence. 17 samples were chosen from 7 different regions with each uniquely represents Indonesian biogeography which comprise Aceh, Riau, Madiun, Blitar, Lombok, South Borneo and Tana Toraja. The result of cyt $b$ gene sequence alignment showed the presence of transition and transversion substitutions and the absence of insertion and deletion The amount of transitions was found to be higher than that of transversions and the amount of substitution in pyrimidine was also higher than that in purine. The highest amount of transitions happened in base $\mathrm{T} \rightarrow \mathrm{C}$ which is a silent substitution. The result of median joining network analysis showed that Indonesian haplotype Bubalus bubalis could be classified into 16 haplotypes which form different haplogroups unique to their geographical region. The result of median joining network analysis also indicated that the genetic relationships of swamp buffaloes (Bubalus bubalis) in Indonesia are highly influenced by their geographical locations.
\end{abstract}

Keywords: Substitution, haplotype diversity, Bubalus bubalis, cyt b gene

\section{Introduction}

There are three kinds of genetic marker: morphological, biochemical, and DNA marker. DNA marker has some characteristics; it has a high rate of polymorphism, is abundant in amount, is uninfluenced by environment and has a rate of heritability of 100 percent. Molecular marker is divided into two kinds: nuclear DNA, and non-nuclear DNA marker. One of the non-nuclear DNA markers mostly used for molecular analyses is mitochondrial DNA (Surahman, 2002). There are two vantage points of mitochondrial DNA: the evolution of mitochondrial DNA happens through the pair substitution of a singular base (Wolstenholme, 1992) and the velocity of mitochondrial DNA evolution is 10 times faster than that of nuclear DNA (Brown et al, 1979).

Mitochondrial DNA contains 13 protein-coding genes and one of them is cyt b protein-coding gene which is seen as a powerful marker for genetic analyses (Arif \& Khan, 2009). Due to the fact that cyt $b$ gene is various and experiences evolution quickly, it is then widely used and is suitable for discovering variations on species level (Bruford et al, 2003). Besides, cyt b is also one of the best samples of mitochondrial DNA of mammals (Arnason \& Gullberg, 1996). Cyt b gene has been used mostly for studying evolution and genetic relationships of mammals, such as that in the studies of cows and buffaloes (Schreiber et al, 1999; Kumar et al, 2007; Li et al, 2007; Qifa et al, 2007; Tobe et al, 2010; Xuan et al, 2010).

In this research, the partial sequence of mitochondrial DNA cyt $b$ is used for identifying the substitution pattern and haplotype diversity of Indonesian swamp buffalo (Bubalus bubalis) as an actualisation for genetic inventory of Indonesian swamp buffalo which is also considered as an indirect endeavour to preserve and to improve the genetic quantity and quality of the population of swamp buffaloes in Indonesia.

\section{Materials and Method}

\section{Blood sample, DNA isolation and PCR}

Blood samples were taken from 17 Indonesian swamp buffaloes (Bubalus bubalis) from 7 sampling regions, comprising Aceh, Riau, Madiun, Blitar, South Borneo, Tana Toraja and Lombok. The swamp buffalo blood was taken through jugular vein using a venoject and vacuum tube and was then mixed with an EDTA material as much as 0.1 gram in order to keep the blood liquid. Next, the tube containing the blood sample was labeled to mark the sample number and location of the blood sampling. The blood was then stored in a refrigerator until the DNA isolation process was conducted.

The process of total DNA isolation was carried out using Nucleospin ${ }^{\mathrm{R}}$ Quickpure Blood Kit and was complied with some established procedures. In order to detect the result of the DNA isolation, agarose gel electrophoresis as much as $0.8 \%$ was used. After that, PCR (Polymerase Chain Reaction) was conducted using a pair of partial mitochondrial DNA cyt $b$ genes with forward primers L14841: 


\section{AAAAAGCTTCCATCCAACATCTCAGCAT}

GATGAAA, and reverse primers H15149: AAACTGCAGCCCCTCAGAATGATATTTG

TCCTCA (Kocher et al, 1989; Irwin et al, 1991). The positions of the primers are illustrated in Figure 1. The process of DNA amplification using PCR consisted of the reaction mixture of 2,5 $\mu 1$ DNA template, $2,5 \mu 1$ forward primers, $2,5 \mu 1$ reverse primers, 12,5 $\mu 1$ PCR mix, and 5,0 $\mu \mathrm{ld} \mathrm{d}_{2} \mathrm{O}$. The PCR process comprised 30 cycles with the following phases: pre-denaturation phase at $93^{\circ} \mathrm{C}$ for 30 seconds, denaturation phase at $93^{\circ} \mathrm{C}$ for 1 minute, annealing phase at $50^{\circ} \mathrm{C}$ for 1 minute, elongation at $72^{\circ} \mathrm{C}$ for 5 minutes and post-elongation phase at $4^{0} \mathrm{C}$.

\section{Sequencing and Data Analysis}

Double-stranded DNA, which is the product of PCR, was then purified and sequenced using one forward primer: AAAAAGCTTCCAT

CCAACATCTCAGCAT GATGAAA (Kocher et al, 1989) using Taq Dye Deoxy Terminator Cycle Sequencing Kit and 373S DNA Sequencer (Perkin Elmer, USA). The total of 17 cyt $b$ gene sequences was then edited using a programme called BioEdit Sequence Alignment Editor and all the cyt $b$ gene sequences were aligned using ClustalX programme (Thompson et al, 1997) with African buffaloes (Syncerus caffer) as the outgroup.

The results of the sequence alignment were then used for discovering the variable and conserved regions, as well as the substitution pattern of the cyt $b$ gene sequences of the Indonesian swamp buffaloes (Bubalus bubalis) which was assisted by the use of MEGA 4 programme (Kumar et al, 2007). In order to discover the haplotype diversity of the Indonesian buffaloes, a median joining network analysis method was conducted using DNA SP and Network 4.1 programme (Bandelt et al, 1999).

\section{Results}

Fragments of DNA which were successfully amplified using a pair of primers L14841 and H15149 in this research were about 307 bp (Anderson et al, 1981; Kohcer et al, 1989; Irwin et al, 1991, and Tanaka et al, 1996). The achieved findings were then confirmed using BLAST (Basic Local Alignment Search Tool) method to discover whether the gained sequences in the research matched with the cyt $\mathrm{b}$ gene sequences of Bubalus bubalis. The result of alignments of the gene sequences with query from Genbank showed the rate of sequences homologous $\geq 200 \mathrm{bp}$ and the similarity rate of $98 \%$. The high percentage of similarity indicated that the sequences gained in this research were the actual sequences of cyt $b$ gene of Bubalus bubalis.

The characteristics of a cyt $b$ gene are that it does not have any stop codon (termination codon) and it has the lowest guanine as well as the highest cytosine of all genes (Avise, 1994). The translation result of the DNA sequences to amino acids found that there was no stop codon found in the whole cyt b gene samples. This showed that the amplified DNA sequences were the target gene sequences.

\section{The Composition of Nucleotide and Variable Region}

The nucleotide base composition of Adenine, Thymine, Guanine and Cytosine is consecutively 29.3\%, 26.7\%, $27.1 \%$ and $16.9 \%$. The total amount of nucleotide $\mathrm{A}+\mathrm{T}=$ $56 \%$ and $\mathrm{G}+\mathrm{C}=44 \%$. Hence, $\mathrm{GC}<\mathrm{AT}$ and this is congruent with what was stated by Sueoka (1962), that the comparison of $\mathbf{C C}<\mathbf{A T}$ is relative equal to the content of GC by $40-45 \%$ in vertebrate.

According to the sample and outgroup sequence alignment result, it was found that the conserved region was bigger than the variable region with the former as much as $80.13 \%$ and the latter as much as $19.87 \%$. This finding showed that Indonesian Bubalus bubalis has quite bigger homologous than African buffaloes, Syncerus caffer. This is because African buffaloes or Syncerus caffer is within the same family with Bubalus bubalis, called Bovidae family, and in the group of buffalo of genus of Bubalus with two different kinds of species: Syncerus caffer and Bubalus bubalis.

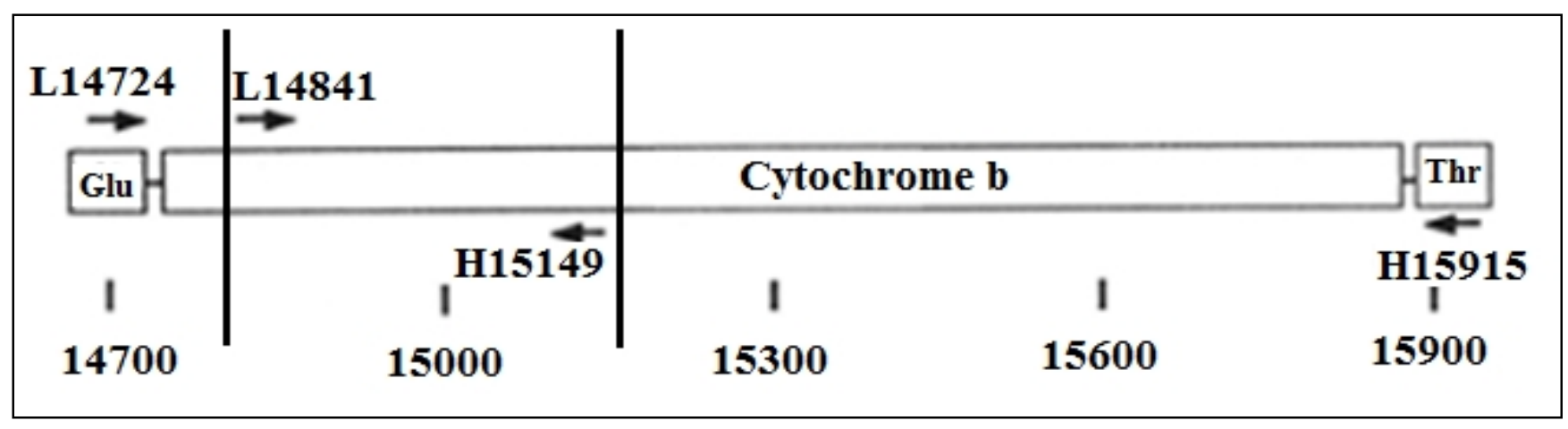

Figure 1. The positions of the primers L14841 and H15149 in Amplifying Mitochondrial DNA Cyt b Gene Sequences (Source: Irwin et al, 1991).

This finding was supported by Cai et al (2013), who studied the phylogeny among goats, cows and buffaloes species under the family of Bovidae based on the SRY gene sequence variations. They found that cows are classified in genus Bos, goats in genus Capra, while buffaloes (both Syncerus caffer and Bubalus bubalis) in 
genus Bubalus. A similar finding was also stated by MacEachern et al (2009) who conducted species phylogeny reconstruction under the cluster of Bovini, who found that species from genus Bubalus and Syncerus are under the same cluster of buffaloes.

\section{Transition and Transversion Substitution}

Cyt $b$ gene has a characteristic of having the amount of transition substitution more than that of transversion (Avise, 1994). This could be observed from the amount of nucleotide base which experienced transition substitutions was 17 , while that which experienced transversion substitution was 6 . (Table 1). The nucleotide base which experienced transition substitutions was the base numbered 7, 31, 47, 64, 76, 94, 127, 148, 163, 167, $172,223,226,230,266,277$, and 288, while the nucleotide base which experienced transversion substitutions was the base numbered 43, 73, 121, 166,
220, and 259. The transition substitutions mostly took place in base $\mathrm{T} \rightarrow \mathrm{C}$ and consecutively followed by $\mathrm{C} \rightarrow \mathrm{T}$, $\mathrm{A} \rightarrow \mathrm{G}$ and $\mathrm{G} \rightarrow \mathrm{A}$, while the transversion substitutions mostly took place in base $\mathrm{A} \rightarrow \mathrm{C}$ and $\mathrm{C} \rightarrow \mathrm{A}$ and consecutively followed by base substitution $\mathrm{T} \rightarrow \mathrm{G}$ and $\mathrm{A} \rightarrow \mathrm{T}$ (Table 1).

The amount of transition substitutions in pyrimidine base excelled that in purine base. It could be observed either from the substitutions of base $\mathrm{T}$ to $\mathrm{C}$ or those of base $\mathrm{C}$ to $\mathrm{T}$ which happened a lot more than the substitutions of base A to $G$ or those of base $G$ to A. A similar finding was reported by Tamura and Nei (1993) and was also supported by Li et al. (2007) who proposed the taxonomy status of Gayal (Bos frontalis) founded on the partial sequence of cyt $b$ gene which showed the amount of substitutions in pyrimidine base $(\mathrm{T} \rightarrow \mathrm{C})$ was more than that in purine base $(A \rightarrow G)$.

Table 1. The Variations of Nucleotide Base of Cyt b Gene Sequences of the Indonesian Bubalus bubalis and of the Outgroup.

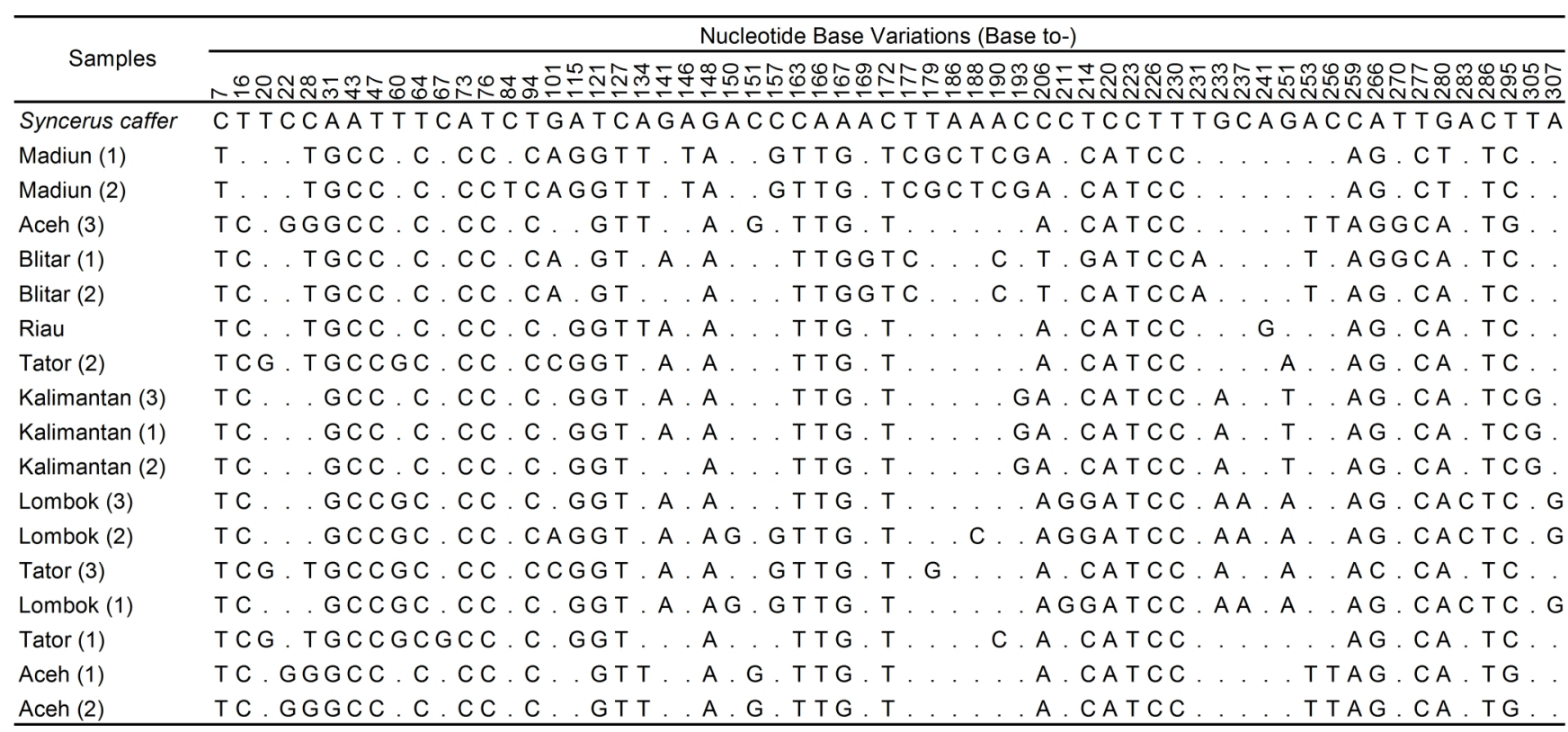

\section{Haplotype Diversity}

The result of median joining network analysis showed that Indonesian Bubalus bubalis could be classified into 16 haplotypes according to their own biogeography (Figure 2). The haplotypes form a haplogroup in accordance to the biogeography of each sample of Indonesian swamp buffalo (Bubalus bubalis). Based on Figure 2, it was known that the variations of nucleotide base between the haplotypes of the buffaloes from the same region were smaller than the variations of nucleotide base between the haplotypes of the buffaloes from different regions. This suggested that the buffaloes from the same region shared a higher rate of genetic relationships than with those from different regions. This phenomenon could be observed from the haplotypes of the buffaloes from Aceh region which formed the haplogroup of Aceh region (A1, A2 and A3) had relatively smaller variations of nucleotide base between themselves than with those of other distant regions (Figure 2).

\section{Discussions}

Table 1 illustrates the absence of insertion or deletion but it indicates the presence of the nucleotide substitutions in $307 \mathrm{bp}$ of the cyt b gene sequence of Indonesian Bubalus bubalis which were transition and transversion substitutions. Transition substitution is a substitution between purine base ( $\mathrm{A}$ and $\mathrm{G}$ ) or between pyrimidine base $(\mathrm{C}$ and $\mathrm{T})$, while transversion substitution is a substitution between purine and pyrimidine base (Graur and $\mathrm{Li}, 2000)$. Cyt $\mathrm{b}$ gene has more transition than transversion substitutions (Brown et al, 1982; Avise, 1994). The same thing happened in this research as there 
were 17 transition substitutions and 6 transversion substitutions. The fact that the transition substitution is higher than transversion substitution is the result of the saturation happens on the divergence levels in purine base is lower than that in pyrimidine base; this makes the frequency of $\mathrm{A}$ and $\mathrm{G}$ base to be much different than the frequency of C and T (Kocher \& Carleton, 1997).

The amount of transition substitutions which was more than the amount of transversion substitutions identified in this research is supported by Winaya (2013) who found that there were 16 transition substitutions of cyt $b$ gene sequence in some kingdoms of cows with the most amount of base substitutions of $\mathrm{T}$ to $\mathrm{C}$ base, and vice versa, from $\mathrm{C}$ to $\mathrm{T}$ base. The substitution of $\mathrm{T}$ to $\mathrm{C}$ base does not necessarily change amino acids since this substitution is silent substitution. This is supported by Anderson et al. (1981), who conducted sequencing and organising the human mitochondrial genome, who remarked that the substitution of $\mathrm{T}$ to $\mathrm{C}$ base is a hidden substitution and does not change amino acids.

Based on the result of median joining network analysis, there were 16 haplotypes of Indonesian Bubalus bubalis (Figure 2). Haplotype is the variation of nucleotide base of a species. The 16 Indonesian haplotypes Bubalus bubalis identified are then classified into 7 different haplogroups: the haplogroup of Borneo (K-1, K-2 and K-3), the haplogroup of Aceh (A-1, A-2 and A-3), the haplogroup of Madiun (M-1 and M-2), the haplogroup of Riau (R-1), the haplogroup of Tana Toraja (T-1, T-2 and T-3), the haplogroup of Lombok L-1, L-2 and L-3) and the haplogroup of Blitar (B-1 and B-2). The result of median joining network analysis showed that each individual of swamp buffalo formed a haplogroup according to their own biogeography, comprising Aceh, Riau, Borneo, Madiun, Blitar, Tana Toraja and Lombok.

This result indicates that the samples taken for this research are actually originated from the locations in which the samplings were conducted. However, a different finding was shown by the haplotype T-1 which was separated from the haplotype T-2 and T-3 even though it is still in the same haplogroup with the two others, the haplogroup of Tana Toraja. This indicates that the sample T-1 is from a different population of T-2 and $\mathrm{T}-3$, although it is still in the same region (Figure 2).

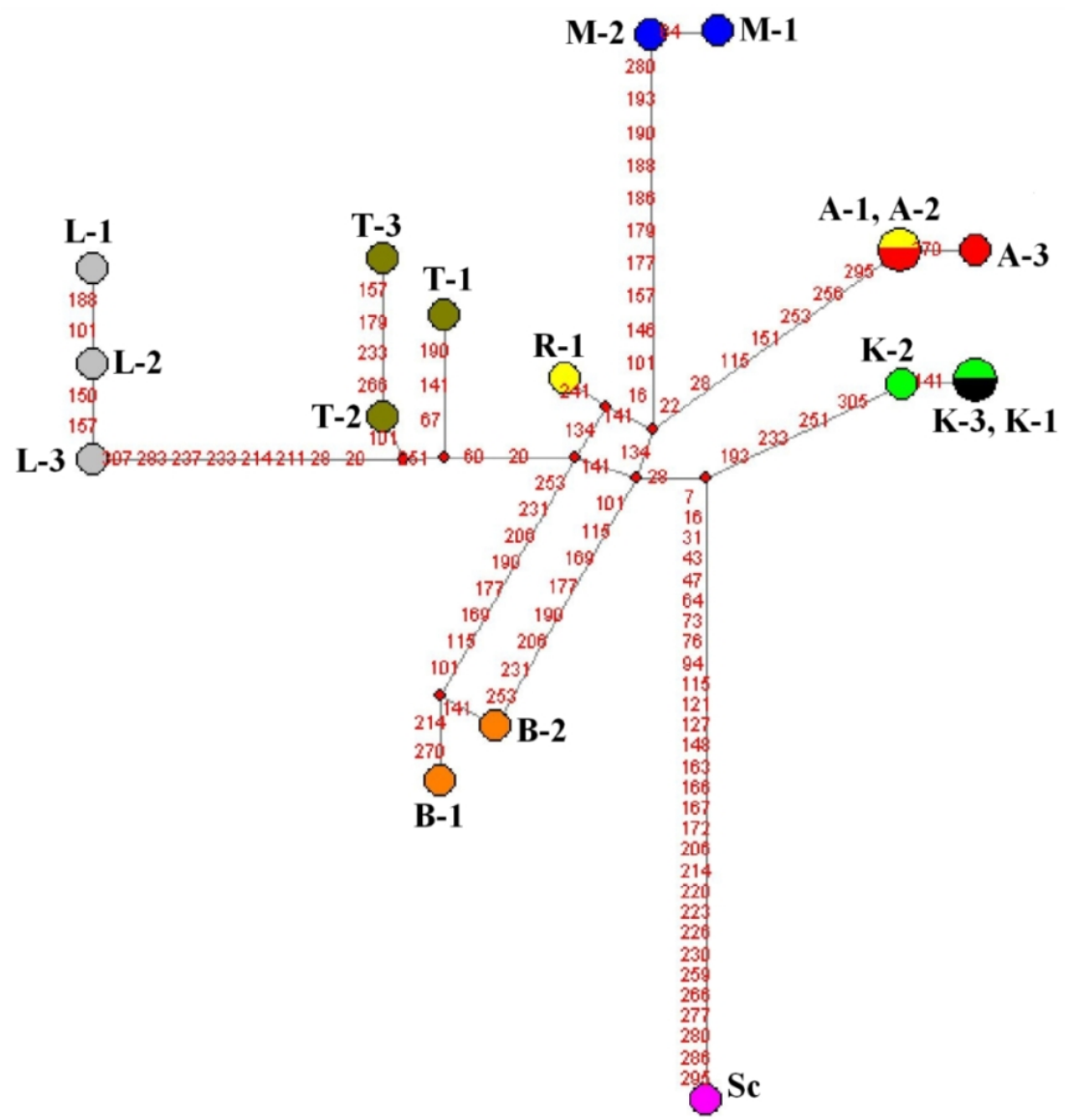

Figure 2. The haplotypes of the Indonesian Bubalus bubalis and the Outgroup Based on the Cyt b Gene Sequences. Haplotype is illustrated in Different Circle Shapes (Big = 2 individuals, Small $=1$ individual). The Red Number in the Branch Point Shows the Position of Various Base between Haplotypes. $\mathrm{L}=$ The buffaloes from Lombok, $\mathrm{T}=$ The buffaloes from Tana Toraja, $\mathrm{M}=$ The buffaloes from Madiun, $\mathrm{R}=\mathrm{The}$ buffaloes from Riau, $\mathrm{A}=$ The buffaloes from Aceh, $\mathrm{K}=$ The buffaloes from Borneo (Kalimantan), B = The buffaloes from Blitar and Sc $=$ Syncerus caffer.

Based on Figure 2, the amount of variations of nucleotide base of each haplotype will be increased along with the improvement of the distance amount between regions or biogeography. This could be observed from the haplotype of Madiun, Aceh and Riau which have one branch point and are separated by the variations of nucleotide base which are relatively small. Nevertheless, the amount of variations of nucleotide base will get increased when the haplotype of Aceh is compared with the haplotype of Lombok which has a huge amount of 
variations of nucleotide base and which biogeographically is very much distant between them. Indirectly, the bigger the variations of nucleotide indicates the more distant the genetic relationships, and this is valid conversely. Therefore, the geographical location or biogeography influences the genetic relationships between Indonesian swamp buffaloes (Bubalus bubalis).

\section{Conclusions}

Based on the analysis result it was found that there were transition and transversion substitutions in cyt $\mathrm{b}$ gene sequences of Indonesian swamp buffaloes (Bubalus bubalis), and there was not any insertion or deletion. Also, it was found that the amount of transition was higher than transversion substitution. The result of median joining network analysis showed that there were 16 haplotypes of Indonesian swamp buffaloes which formed different haplogroups based on their own region or biogeography. Hence, it was concluded that the geographical location influenced the relatives rate or genetic relationships of Indonesian swamp buffaloes (Bubalus bubalis).

\section{Acknowledgments}

The authors would like to thank the Fund Management Institution of Education Ministry of Finance of the Republic of Indonesia, which has funded this research (No:PRJ 481/LPDP/2013).

\section{References}

Anderson, S.,Bankier, A.T.,Barrel, B.G.,de Bruijn, M.H.L.,Coulson, A.R.,Drouin, J.,Eperon, I.C.,Nierlich, D.P.,Roe, B.A.,Sanger, F.,Schrier, P.H.,Smith, A.J.H.,Staden, R.,\& Young, I.G. 1981. Sequences and organization of the human mitochondrial genome, Nature, Vol 290: 457-465.

Arif, I.A \& Khan, H.A. 2009. Molecular markers for biodiversity analysis of wildlife animals: a brief review. Anim. Biodiv and Conserv. Vol 32 (1): 9-17.

Arnason, U \& Gullberg, A. 1996. Cytochrome b nucleotide sequences and the identification of five primary lineage of Extant Cetaceans. Mol Biol Evol, 13(2): 407-417.

Avise, J.C. 1994. Molecular markers, natural history \& evolution. New York: Chapman \& Hall.

Bandelts, H.J.,Forster, P.,\& Rohl, A. 1999. Median joining network for inferring intraspesific phylogenies, Molecular Biological Evolution, 16: 37-48.

Brown, W.M.,George, Jr.M.,\& Wilson, A.C. 1979. Rapid evolution of mitochondrial DNA. Proceeding of the National Academy and Science of USA, 76: 1967-1971.

Brown, W.M.,Prager, E.M.,Wang, A.,\& Wilson, A.C. 1982. Mitochondrial DNA sequences of primates: tempo and mode of evolution, J.Mol.Evol, Vol 18: 225-239.

Bruford, M.W.,Bradley, D.G.,\& Luikart, G. 2003. DNA markers reveal the complexity of livestock domestication. Genetics, Vol 4: $900-910$
Cai, X.,Zhang, H., \& Mipam, T.D. 2013. Unique variations of SRY gene result in distinct patrilineal phylogeny of Capra hircus and another domestic Bovidae, Animal Science Papers and Reports, Vol 30(3): 219-227.

Graur, D. \& Li, W.H. 2000. Fundamentals of molecular evolution. USA: Sinauer Associates Inc.

Irwin, D.M.,Kocher, T.D.,\& Wilson, A.C. 1991. Evolution of the Cytochrome b gene of Mammals, J Mol Evol, Vol 32: 128-144.

Kocher, T.D.,Thomas, W.K.,Meyer, A.,Edwards, S.V.,Paabo, S.,Villablanca, F.X.,\& Wilson, A.C. 1989. Dynamics of mitochondrial DNA evolution in animals: amplification and sequencing with conserved primers, Proc.Natl.Acad.Sci, Vol 86: 6196-6200

Kocher, R.D \& Carleton, K.L. 1997. Base substitution in fish mitochondrial DNA: pattern and rates. In Molecular Systematics on Fish. Kocher, T.D and Ca Stepien (Eds.). Academic Press: San Diego.

Kumar, S.,Nagarajan, M.,Sandhu, S.,Kumar, N.,Behl, V.,\& Nishanth, G. 2007. Mitochondrial DNA analysis of Indian water buffalo support distinct genetic origin of river and swamp buffalo, Animal genetics, 38:227-232.

Li, S.,Chang, H.,Ma, G.,Chen, H.,Ji, D.,\& Geng, R. 2007. The origin taxonomic status of the gayal based on cytochrome $b$ gene partial sequences, Research Journal of Animal Sciences, Vol 1(4):114-119.

MacEachern, S.,McEwan, J, \& Goodard, M. 2009. Phylogenetic reconstruction and the identification of ancient polymorphism in the Bovini tribe (Bovidae, Bovinae), BMC Genomics, Vol 10: 2-17.

Qifa, L.,Yinxia, L.,Xingbo, Z.,Zhenshan, L.,Yefen, X.,Dawei, S.,Xunguang, Q.,Ning, L.,\& Zhuang, X. 2007. Study on the origin and taxonomic status of yak (Poephagus) using cytochrome b gene of mitochondrial DNA, Front Agric China, Vol 1(3): 329-333.

Schreiber, A.,Seibold, I.,Notzold, G.,\& Wink, M. 1999. Cytochrome $\mathrm{b}$ gene haplotypes characterize chromosomal lineages of Anoa, the Sulawesi dwarf buffalo (Bovidae: Bubalus sp), The American Genetics Association, 90: 165-176.

Surahman, M. 2002. Peta genetika tanaman, prinsip dan aplikasinya. Bul.Agron, Vol 30 (1): 27-30.

Tamura, K dan Nei, M. 1993. Estimation of the number of nucleotida substitutions in the control region of mitochondrial DNA in humans and chimpanzees, Mol. Biol. Evol, Vol 10: 512-526.

Tanaka, K.,Solis, C.D.,Masangkay, J.S.,Maeda, K.,Kawamoto, Y.,\& Namikawa, T. 1996. Phylogenetic relationship among all living species of the genus Bubalus based on DNA sequences of the cytochrome b gene, Biochemical Genetics, Vol 34: 443452.

Thompson, J.D.,Gibson, T.J.,Plewniak, F.,Jeanmough, F.,\& Higgins, D.G. 1997. The Clustal-X windows interface: flexible stategies for multiple sequences alignment aided by quality analysis tools, Nucleic Acids Research, Vol 25: 4876-4882.

Tobe, S.S.,Kitchener, A.C.,\& Linacre, M.T. 2010. Reconstructing mammalian phylogenies: a detailed comparison of the cytochrome $b$ and cytochrome oxidase subunit I mitochondrial genes, Mammalian Phylogeny Best Gene, Vol 5:1-14.

Winaya, A. 2010. Variasi Genetik dan Hubungan Filogenetik Populasi Sapi Lokal Indonesia Berdasarkan Penciri Molekuler DNA Mikrosatelit Kromosom Y dan Gen Cytochrome b. Disertasi tidak diterbitkan. Bogor: Institut Pertanian Bogor.

Wolstenholme, D.R. 1992. Animal mitochondrial DNA: structure and evolution, International Review of Cytology, 141: 173-215.

Xuan, T.P.,Georgescu, S.E., Manea, M.A., Hermenean, A.O., \& Costache, M. 2010. Genetic diversity and phylogenetic relationship of Romanian cattle breeds inferred from cytochrome $b$ gene partial sequences, Romaian Biotechnological Letters, Vol 15(2): 5154-5158. 
